\title{
O Espírito da Escola de Samba nos corredores da Rádio Nacional
}

\section{Walter Garcia'}

Instituto de Estudos Brasileiros da Universidade de São Paulo, Brasil

waltergarcia@usp.br

Fecha de recepción: 7/6/2021. Fecha de aceptación: 1/7/2021.

\section{Resumo}

Este ensaio estuda os sentidos do samba "Fechou o paletó" (Zé Kéti) no filme Rio Zona Norte, de Nelson Pereira dos Santos, de 1957. Analisam-se os elementos musicais da sua apresentação, com destaque para a harmonia característica dos conjuntos regionais. Interpretam-se os elementos da narrativa que compõem "a alma" da canção, uma experiência complexa formada no trânsito entre malandragem e delinquência, trabalho formal e trabalho informal. E discute-se o encontro frustrado entre Espírito da Luz Soares, um sambista negro morador do morro, e a cantora Ângela Maria, grande nome da Rádio Nacional do Rio de Janeiro.

Palavras-chave: Música popular brasileira; cinema brasileiro; samba; sociedade brasileira contemporânea.

The Spirit of the Samba School in the Hall of National Radio of Rio de Janeiro

\footnotetext{
Abstract

This paper studies the senses of samba "Fechou o paletó" (Zé Kéti) in the movie Rio Zona Norte (1957), directed by Nelson Pereira dos Santos. It analyzes the musical elements of its presentation, highlighting the characteristic harmony of conjuntos regionais. It interprets the narrative elements that make up 
"the soul" of the song, a complex experience formed in the relationship between malandragem and delinquency, employment and casual job. Finally, it discusses the frustrated meeting between Espírito da Luz Soares, a black man, samba composer who lives in the favela, and the singer Ângela Maria, a great artist of National Radio of Rio de Janeiro.

Keywords: Brazilian Popular Music; Brazilian Cinema; Samba; Contemporary Brazilian Society.

A abertura de Rio, Zona Norte, filme dirigido por Nelson Pereira dos Santos (1957), nos leva à avenida Presidente Vargas enquanto escutamos a orquestra ora acompanhar o ritmo frenético do final de um dia útil, ora desacelerar e sugerir outra dinâmica de vida (Fabris, 1994, p.157). ${ }^{2}$ Vemos a torre da estação Dom Pedro II, o relógio que marca 17h50, somos colocados dentro do trem, passamos pelo canal do Mangue, vemos a paisagem do subúrbio. A intenção parece clara, conduzir o público de classe média e o de classe alta para a Zona Norte, onde habita o protagonista Espírito da Luz Soares - ou, como ele se identificará à porta de uma residência na Zona Sul, "o Espírito da Escola de Samba". Mas três homens socorrem um pingente que caiu nos trilhos da Estrada de Ferro Central do Brasil. Um deles vai chamar o encarregado da linha e não volta mais ao local. Um grande ferimento na têmpora esquerda. 0 ruído dos trens correndo se funde a uma batucada de samba. Deitado, o personagem Espírito - representado por Grande Otelo - mexe a cabeça, abre lentamente os olhos.

A partir de então, a narrativa de Rio, Zona Norte se desenvolverá parcialmente em flashback. Assistiremos às recordações de Espírito, um sambista negro, como se estivéssemos dentro da sua mente, compartilhando suas emoções. As lembranças serão organizadas em blocos. Ao final de cada bloco, o flashback será quebrado pelo atendimento no hospital Souza Aguiar (Fabris, 1994, p.159160). Assim como ocorre na estrutura geral da narrativa, dois pontos de vista principais irão se alternar em cada uma das cenas: o de Espírito da Luz Soares, personagem-narrador; e o do diretor, narrador que se debruça "sobre aquela realidade" (Fabris, 1994, p.158). A relação entre esses dois pontos de vista oscilará entre o distanciamento e a busca de identificação que o olhar externo lançará em direção à "classe popular e sua cultura” (Silva, 2013, p.82).

Neste ensaio, meu objetivo é discutir um aspecto ainda não suficientemente explorado na crítica do filme. Com grande acerto, estudos como o de Mariarosaria Fabris (1994, p.196-199), o de Carolinne Mendes da Silva (2013, p.50 e 174) e o de Marcos Napolitano (2014, p.81-83) identificaram os impasses e os limites das expectativas que o ponto de vista do narrador externo deposita no encontro, frustrado em Rio, Zona Norte, entre Espírito da Luz Soares e o violinista Moacyr - representado por Paulo Goulart. De modo mais específico, impasses e limites de um projeto de balé que faria a síntese da produção popular com 
a arte erudita, "de corte nacionalista e progressista" (Napolitano, 2014, p.83). Sem desconsiderar formulações desses estudos, o que se tornará evidente ao longo do ensaio, meu objetivo se alinha com questões trabalhadas por Luis Felipe Kojima Hirano (2014, p. 245-246) ao analisar a construção complexa de Espírito da Luz Soares, "cercada de elementos que lhe dão integridade e maturidade", e examinar seu "projeto de vida". Pretendo chamar atenção para um ponto-chave desse projeto: a esperança, também frustrada, que o personagemnarrador deposita no encontro com a cantora Ângela Maria. Em outras palavras, no encontro entre o samba de terreiro - que fala "o que se vive, o que se faz" de forma direta ou transfigurada, celebrando "os sentimentos vividos, as convicções, as emoções, os sentimentos reais" (Sodré, 1998, p.44-45; grifos do autor) - e a artista do disco e do rádio que, com sua atuação no mercado hegemônico, valorizaria a música.

\section{Nos corredores da Rádio Nacional}

Na perspectiva dessa esperança, a melhor síntese do filme Rio, Zona Norte é a sequência que tem início quando Espírito da Luz Soares toma coragem para se aproximar de Ângela Maria e lhe oferecer uma composição. Ela deixa o auditório da Rádio Nacional do Rio de Janeiro, cercada de fãs, e distribui autógrafos. Espírito segura um papel, mostra-o à cantora e fala, olhando quase sempre para baixo:

ESPÍRITO - Eu trouxe um samba pra mostrar pra senhora.

[Ângela Maria coloca a mão no ombro de Espírito.]

ÂNGELA MARIA - Eu ouvirei com muito prazer. Vamos fazer o seguinte, vamos ao bar, enquanto eu tomo um cafezinho, você canta o samba pra mim. Tá bom, meu bem?

ESPÍRITO - Tá, sim, senhora.

ÂNGELA MARIA - Então vamos, vamos lá.

ESPÍRITO - Obrigado!

ÂNGELA MARIA - [Para o servente] Um café. [Para Espírito] Pode cantar seu samba.

[Espírito entrega a Ângela Maria o papel com a letra do samba. Depois pega no bolso uma caixa de fósforo para batucar (Santos, 1957).]

É significativo que o samba seja apresentado dessa forma simples. A princípio, não há exagero em afirmar que três elementos comuns na prática da música de tradição oral - tradição que não é necessariamente ágrafa - estão presentes na cena:

a) a letra escrita;

b) o canto do autor;

c) o acompanhamento percussivo; executado, na cena, pelo próprio compositor, este acompanhamento é fundamental para que o ritmo seja sentido e compreendido por quem escuta. 
Mas a sequência não recria exatamente a vigência da música de tradição oral. Iniciando-se em um corredor da Rádio Nacional e continuando no bar da empresa, recria, sim, algumas das tensões que caracterizavam o processo de transformação da composição popular criada sobre base percussiva, sem apoio de instrumento melódico-harmônico, em obra fonográfica na então capital do país, na década de 1950. É por isso que a melhor percussão é aquela que mantém a intensidade baixa: a pulsação rítmica não deve competir com a emissão da voz. E é por isso também que a ausência de partitura musical estará implicada no trágico fim de Espírito da Luz Soares e, por tabela, no provável desaparecimento do samba (refiro-me, é óbvio, à narrativa cinematográfica).

Voltemos a Rio, Zona Norte. Acompanhando-se com a caixa de fósforo, Espírito agora não olha para baixo, mas para Ângela Maria, e canta os quatro versos da parte A e o primeiro verso da parte B (refrão) de "Fechou o paletó", de autoria de Zé Kéti, ${ }^{3}$ samba que receberia o título de "Malvadeza Durão" a partir do show Opinião, apresentado em 1964 e 1965 :

\author{
[parte A] \\ Mais um malandro fechou o paletó \\ Eu tive dó, eu tive dó \\ Quatro velas acesas em cima de uma mesa \\ E uma subscrição para ser enterrado \\ [parte B] \\ Morreu Malvadeza Durão... (Santos, 1957).
}

Quando a parte B se inicia, vemos ao fundo um homem andando, carregando um violão. Ele se coloca atrás de Espírito e, ao final do primeiro verso, começa a tocar. Sem parar de cantar, Espírito deixa de bater na caixa de fósforo e volta o rosto apenas para se certificar da presença do violonista. O novo acompanhamento não prejudicará a verossimilhança. As análises musicais que se seguirão têm por finalidade aprofundar o estudo da narrativa, mas a leitora ou o leitor que não conheça um pouco de teoria musical poderá passar diretamente para a Fig. 1 .

O violonista basicamente executará acordes característicos do samba e do choro tocados pelos conjuntos regionais naquela década de 1950: primeira do Dó (acorde C), segunda do Dó (acorde G7), preparação (acorde A7), terceira menor do Dó (acorde Dm); ${ }^{4}$ ainda dentro desse idioma, há inversão de alguns acordes e serão

3 O título "Fechou o paletó" pode ser lido na ficha técnica do filme (Santos, 1957). Zé Kéti, amigo pessoal de Nelson Pereira dos Santos, "'serviu de base, como ponto de partida'" para a história, segundo o próprio diretor afirmou em entrevista a Mariarosaria Fabris (1994, p. 153): "pensou na história do compositor, foi morar na casa dele, levantou todas as músicas não editadas (200/300), que ele compunha no ônibus, em papel de padaria, cadernos, etc., impressionado com o fato de que, não tendo como registrá-las, ficava muito pouco do que ele produzia". Além de compor para o filme, Zé Kéti trabalhou como ator representando Alaor da Costa, cantor em ascensão que participa de duas negociações informais conduzidas por Maurício Silva (representado por Jece Valadão), por meio das quais, sucessivamente, Espírito da Luz Soares é passado para trás no mercado do rádio e na indústria do disco.

4 Em seu método de violão, cujo copyright é de 1961, Fernando Azevedo explica de modo simples e prático a origem dos termos que designam os "acordes principais característicos" de cada tonalidade: "No estudo de cada tom, eles são os que se fazem em primeiro e segundo lugar, respectivamente". Em outras palavras, em primeiro 
tocadas algumas baixarias, ou seja, frases nos bordões (cordas mais graves). ${ }^{5}$ No âmbito da verossimilhança, nada que um profissional não pudesse executar no bar da Rádio Nacional, mesmo sem nunca ter escutado aquela canção. A análise harmônica tornará mais claro o que afirmo.

Com a entrada do violão, Espírito retomará o início do samba, deixando evidente que o instrumento valorizava a sua composição. Observemos agora a relação entre a melodia e os acordes tocados na repetição da parte A.

No início do primeiro verso ("Mais um malandro fechou o paletó"), a relação entre a melodia criada por Zé Kéti e o acompanhamento do violão tem por efeito a sobreposição da $11^{\text {a }}$ ao acorde de $\mathrm{Dm}$ - a nota sol é a primeira nota cantada. Já ao final do verso, Espírito canta a 7a menor (nota si bemol), e o violão executa o acorde de $\mathrm{C} 7^{(9)}$. Esse é o único caso de acorde em que há uma nota de tensão, a 9a maior - uma nota, aliás, que não é requerida pela melodia. $O$ acorde é o I grau do modo mixolídio de Dó. Trata-se, portanto, de empréstimo modal: $C 7^{(9)}$ tem função de tônica e concentra, de forma breve e passageira, ou a prática do blues (afinal, a $7^{a}$ menor é uma blue note), ou a dos standards dos songwriters estadunidenses (os quais, dentre outros recursos, utilizaram blue notes), ou o acompanhamento dos conjuntos vocais brasileiros (que se apropriaram de recursos da canção estadunidense), ou - quem sabe - a escuta do baião (gênero que se distingue musicalmente, dentre outros traços, pelo uso do modo mixolídio). ${ }^{6}$

Já quando Espírito canta o verso “Quatro velas acesas”, as duas notas finais, dó e si, criam tensões com o acorde de $\mathrm{Dm}$ (como se sabe, trata-se respectivamente da $7^{a}$ menor e da $6^{a}$ maior). E as duas notas finais com que o sambista canta "em cima de uma mesa", si e lá, novamente criam tensões com o acorde de $C$ do violão (como se sabe, trata-se da $7^{a}$ maior e da $6^{a}$ maior, respectivamente). Essas passagens sugerem que a melodia poderia ter sido acompanhada por uma estrutura harmônica diversa para que ficasse apoiada com maior consonância ou, de outro ângulo, para que ficasse apoiada com maior rendimento dos efeitos de consonância imperfeita (6a maior) ou de dissonância (além da 7a menor e da 7a maior referidas, há o intervalo entre a nota fá, do acorde de Dm, e a nota sol da voz, quando Espírito canta "Mais um malandro fechou"; como se sabe, a nota sol é a $11^{\text {a }}$ do acorde de $\left.\mathrm{Dm}\right)$. De todo modo, sempre se deve lembrar que escutamos um idioma específico, o dos conjuntos regionais, o que justifica as escolhas do violonista.

lugar se estuda o acorde de tônica; em segundo lugar, o acorde de dominante; em terceiro lugar, o acorde de subdominante e o seu relativo menor, daí os termos "terceira maior" e "terceira menor" (Azevedo, s.d., p.8).

5 Segundo José Ramos Tinhorão, "a partir da década de 1880, com a proliferação dos pequenos grupos de flauta violão e cavaquinho, transformados em acompanhadores do canto das modinhas sentimentais e tocadores de polcas-serenatas à noite, pelas ruas, e em orquestras de pobre, para fornecimento de música de dança nas casas dos bairros e subúrbios cariocas mais humildes, a música do choro vai se tornar cada vez mais popular. Espalha-se então pelo Brasil o achado da sua baixaria, só destronada na década de [1930], quando os violonistas dos chamados conjuntos regionais da era do samba batucado adotam o acompanhamento de ritmo de percussão" (1991, p.105).

6 Para a análise harmônica, baseio-me em Almir Chediak (1984) e nos estudos de Harmonia e de Rearmonização que realizei com o maestro Cláudio Leal Ferreira. 
Contudo, as tensões entre a melodia e a sequência de acordes se acentuam bastante quando Espírito canta "Uma subscrição para ser enterrado". Inicialmente, a nota lá, rebatida em "Uma", é a 6a maior do acorde C, o que não traz novidades frente ao que já ouvimos. E a nota sol, rebatida em "para", é a 11 a do acorde Dm, efeito que também já escutamos. Mas a nota ré, rebatida em "enterra-", é a $4^{a}$ justa do acorde de A7. Dentro das relações da tonalidade no repertório de sambas do período, a sobreposição da $4^{\text {a }}$ ao acorde maior com sétima soa como erro. 0 efeito acaba por acentuar a tensão entre a nota final si cantada na última sílaba do verso, "enterrado", e o acorde de Dm/C. De um lado, na chave da verossimilhança, assistimos a um violonista que toca de improviso, como já assinalei. De outro, os "desencontros entre a harmonia sugerida pela melodia (...) e os acordes efetivamente executados" indicam um "desencaixe entre a expectativa" do violonista, que toca conforme "modelos interiorizados pela prática" (Rezende, 2021, p.65-66), ${ }^{7}$ e a construção melódica de Zé Kéti cantada por Grande Otelo, no papel de Espírito.

Abrirei parênteses. Esses desencontros entre melodia e harmonia seriam resolvidos na década de 1960, no trabalho da então chamada segunda geração da bossa nova. "Malvadeza Durão" foi interpretado por Zé Kéti em Opinião, como se escuta no registro do show em disco (Kéti, 2002). E também foi gravado por Nara Leão para o disco $O$ canto livre de Nara, de 1965 (Leão, 2002). Nos dois fonogramas, o violonista é Dori Caymmi. Em que pese a diferença entre as tonalidades (Lá maior e Sol maior, respectivamente), as duas gravações mantiveram semelhantes a sintaxe e a morfologia dos acordes. Sintaxe e morfologia não mais desenvolvidas no âmbito dos conjuntos regionais, e sim no âmbito da linguagem que toma por referência principal os três primeiros LPs de João Gilberto. Embora rechaçados no calor da hora por uma parte da crítica nacionalista, ${ }^{8}$ os acordes dissonantes não eram, portanto, estranhos à melodia de Zé Kéti. Nas décadas seguintes, esse tipo de arranjo prevaleceu. Tome-se como exemplo a interpretação de Juçara Marçal (na tonalidade de Mi maior) de "Malvadeza Durão" no show Cancioneiro de Boal, apresentado em 2012, em São Paulo. ${ }^{9}$

7 Gabriel Sampaio Souza Lima Rezende (2021, p. 65-66) se refere, na passagem que cito, ao acompanhamento de "Rosa", de Pixinguinha, ainda sem letra e com andamento de "valsa 'saltitante"', em gravação realizada em 1917. Desse modo, fica sugerida a duração do chamado processo de modernização da música popular brasileira que teve por base o diálogo com danças da moda que chegavam da Europa, a "tradição europeia da música 'erudita'" (Rezende, 2021, p. 92) e recursos da música popular estadunidense.

8 Estou me referindo, em especial, a José Ramos Tinhorão. Para ficar em um só exemplo literalmente digno de nota: "uma curiosa evolução que, partindo de pobres negros barbeiros, de pé no chão, passaria sucessivamente aos mestiços da baixa classe média do fim do século XIX, conhecidos por chorões, e aos músicos profissionais do rádio das três primeiras décadas do presente século, para chegar aos rapazes bem da década de 60, cultivadores da chamada bossa nova. Longo caminho de ascensão social que explica, afınal de contas, a perda de substância cada vez maior do ritmo original, em favor de uma harmonização internacionalista, que não deixa de constituir uma moderna incapacidade de renovar a música carioca, sem sair da tradição" (Tinhorão, 1997, p.133).

9 Vale assinalar que o principal recurso utilizado em "Malvadeza Durão", no show Cancioneiro de Boal, em 2012, veio da linguagem cancional, não da musical. Interpostos aos versos de Zé Kéti, sobre base percussiva, Juçara Marçal entoou alguns versos de "Tô ouvindo alguém me chamar", rap de Mano Brown (Racionais, 1997): "Mais um malandro fechou o paletó/ Eu tive dó, eu tive dó/ Quatro velas acesas em cima de uma mesa/ E uma subscrição para ser enterrado// Eu tô ouvindo alguém meu nome/ Parece um mano meu, é voz de homem/ Eu não consigo ouvir quem me chama/ Parece a voz do Guina, Guina não, Guina tá em cana// (...) Morreu Malvadeza Durão/ E o criminoso ninguém viu/ E o criminoso ninguém viu// Dez minutos atrás, foi como uma premonição/ Dois moleques caminhando em minha direção/ Não vou correr, eu sei do que se trata/ É isso que eles querem, então vêm, me mata" (Marçal, 2012). 
Parênteses fechado, a forma musical de "Fechou o paletó", em Rio, Zona Norte, presumivelmente seria A, B (refrão), C, B' (refrão com variação na segunda frase), B'. Mas, como Espírito retoma o início do samba após a entrada do violão, ele acaba cantando a forma musical A, B, A, B, C, B'. É nesse ponto que Ângela Maria, que escutava olhando para o compositor e lendo a letra, entra cantando a parte C. Uma vez mais, a verossimilhança não será afetada. A câmera permanecerá em Espírito cerca de 15 segundos, tempo suficiente para presenciarmos sua "espontânea felicidade" (Silva, 2006, p.48). Atrás dele, à esquerda, o violonista dirigirá o olhar para Ângela. E à frente de Espírito, à direita, uma das fãs da cantora observará, sorrindo, a reação do compositor (Fig. 1):

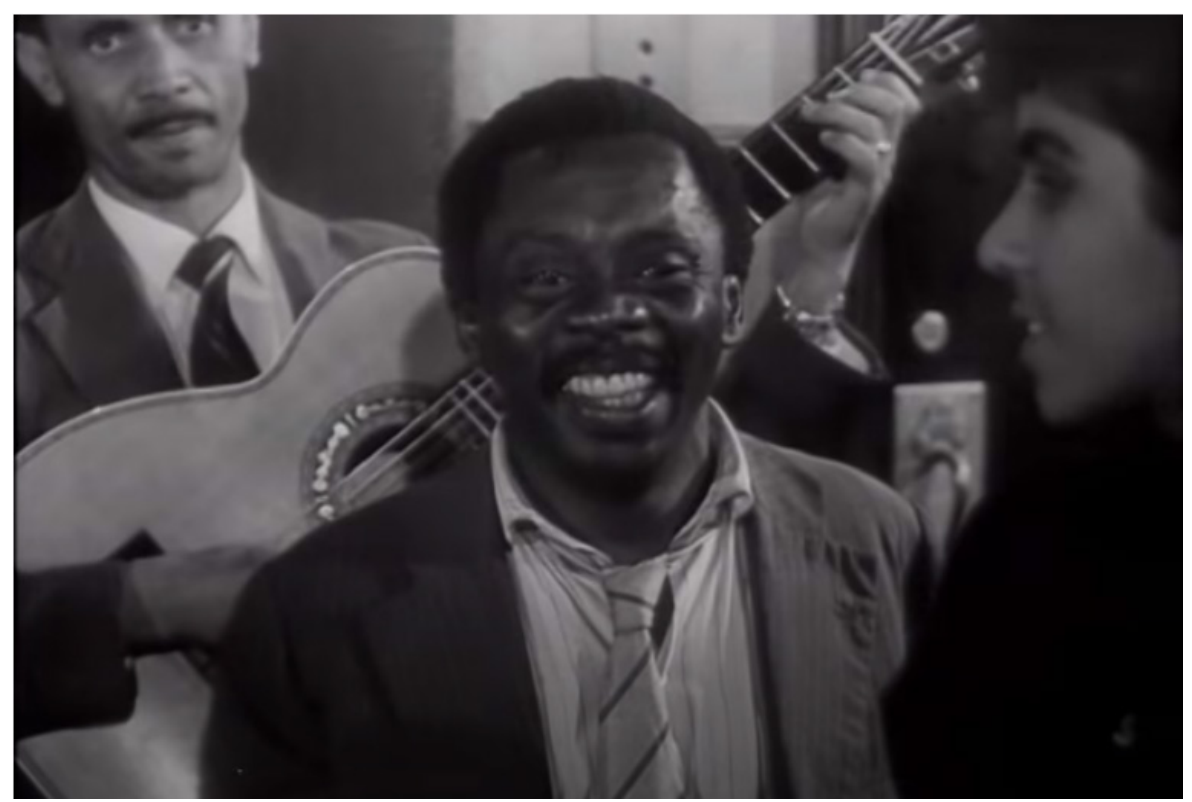

Fig. 1: A câmera em Espírito da Luz Soares, quando Ângela Maria começa a cantar "Fechou o paletó"

A apresentação do samba no bar da Rádio Nacional, assim, nos fará escutar a seguinte letra:

[parte A - Espírito, voz e caixinha de fósforo]

Mais um malandro fechou o paletó

Eu tive dó, eu tive dó

Quatro velas acesas em cima de uma mesa

E uma subscrição para ser enterrado

[parte B]

Morreu Malvadeza Durão [entrada do violão]

Valente, mas muito considerado

[parte A]

Mais um malandro fechou o paletó

Eu tive dó, eu tive dó

Quatro velas acesas em cima de uma mesa

E uma subscrição para ser enterrado 


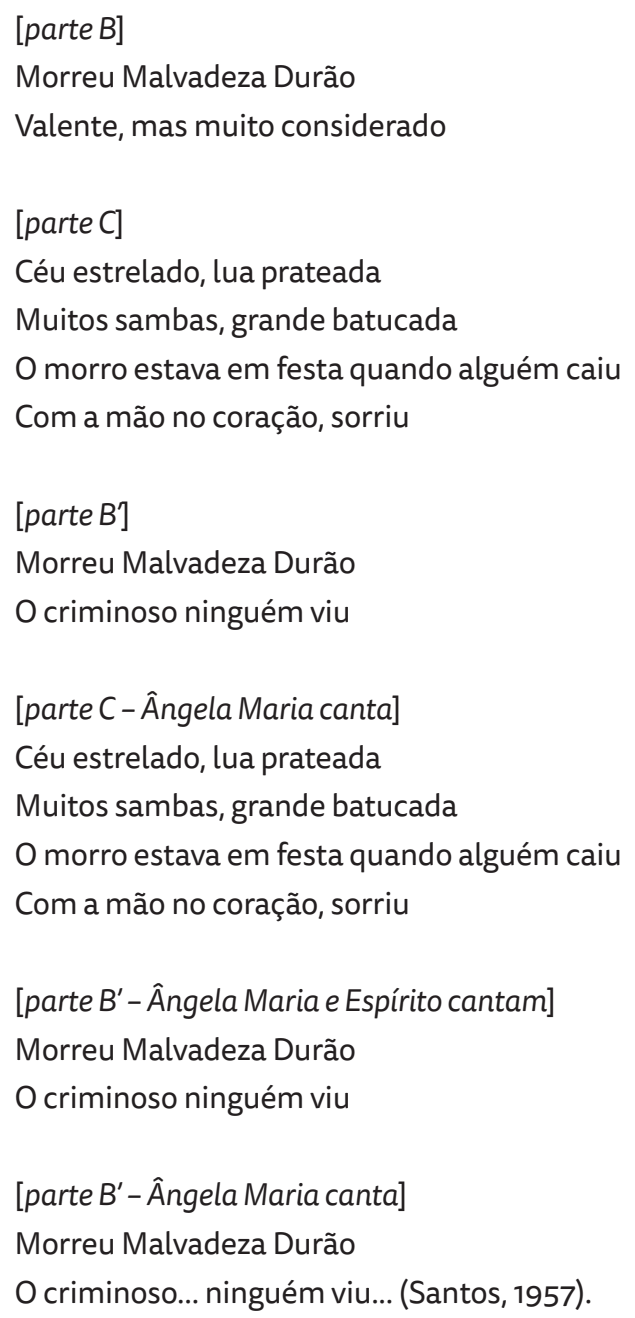

Ao terminar o samba, Ângela Maria elogia: “Fabuloso, meus parabéns, a música é minha. Você traga a parte de piano, que eu vou mandar fazer um bonito arranjo e vou gravar”. E, colocando a mão no ombro de Espírito, pergunta: “Tá satisfeito?”. Como se nota, a simpatia e a condescendência aí se misturam. Espírito agradece mais uma vez: “Obrigado!”. E a cantora vai embora, levando o papel com a letra de "Fechou o paletó" (Santos, 1957).

\section{Ângela Maria}

No fluxo de recordações de Rio, Zona Norte, essa é a terceira vez que vemos Espírito da Luz Soares na Rádio Nacional. Na primeira, o sambista apenas assistira a Ângela Maria interpretar, com acompanhamento de orquestra, o samba-canção - ou, caso se prefira, o sambolero - "Pretexto" (Herondino Silva/ Augusto Mesquita). Espírito lhe dirigira do auditório, então, um olhar cujo sentido não é fácil de precisar, como tampouco é fácil definir a expressão do seu rosto (Fig. 2). Mas, correndo o risco de atropelar a exposição do argumento, digamos que o sambista 
parecia vislumbrar a "realização de um sonho factível" (Hirano, 2014, p.246), o que significaria constituir uma presença efetiva no mundo.

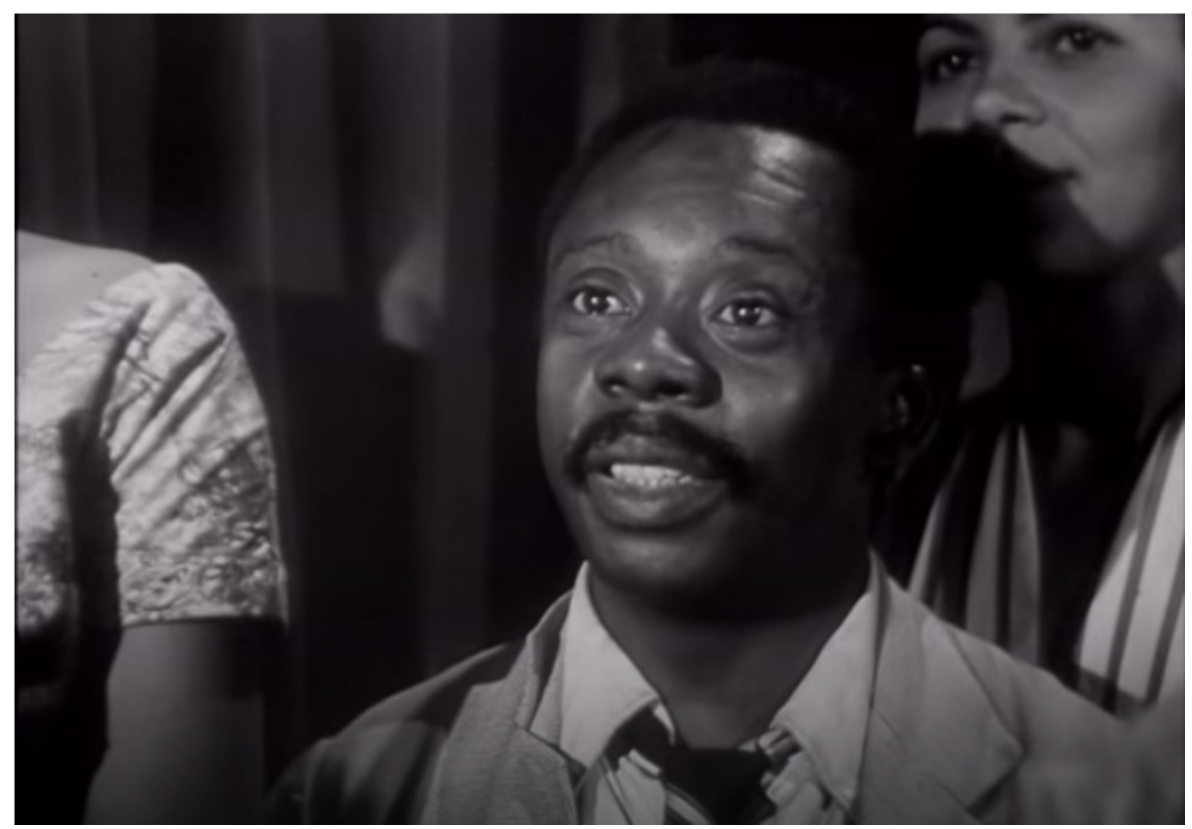

Fig. 2: No auditório da Rádio Nacional, Espírito assiste a Ângela Maria cantar o samba-canção "Pretexto"

Ao sair do auditório, Espírito conversou com outro compositor, que lhe disse sobre Ângela Maria: “Ela valoriza a música da gente. Ela sabe interpretar com alma”. Poderia ser um lugar-comum. Em Rio, Zona Norte, não é. O comentário se refere tanto à valorização comercial quanto à valorização estética. A valorização comercial diz respeito, em síntese, ao sucesso de Ângela Maria - "a grande cantora do Brasil” na época (Aguiar, 2002, p.76), "eleita Rainha do Rádio em 1954" (Sovik, 2006, p. 9), herdeira "de uma tradição inaugurada por Carmen Miranda, nos anos 30" (Aguiar, 2002, p.82), ${ }^{10}$ - e ao alcance da Rádio Nacional (Saroldi y Moreira, 1988). Sem menosprezar esses aspectos, que são fundamentais para o entendimento do que está em jogo, vou me deter na valorização estética.

Quando aquele compositor afirma que Ângela Maria “sabe interpretar com alma”, obviamente está se referindo à técnica expressionista, aos recursos que impregnam de afetos as canções, "com uma projeção de emoção teatralizada" (Sovik, 2006, p.11). Devemos lembrar que o estilo da cantora foi marcado por um forte sentimentalismo. Ocorre que o alumbramento de Espírito, enquanto vê Ângela Maria cantar "Pretexto", indica que o compositor não enxerga sentimentalismo, mas sim, sentimentos. Essa questão, se não estou equivocado, ainda não foi analisada em profundidade por estudos de Rio, Zona Norte que se mantiveram muito próximos do ponto de vista do narrador externo; se não, identificados com o ponto de vista do personagem Moacyr, violinista que toca na orquestra da Rádio

10 Liv Sovik afirma que vencer a eleição de Rainha do Rádio, em 1954, foi "o momento inicial de uma década de grande sucesso. [Ângela Maria] foi capa da Revista do Rádio 52 vezes - número excedido só por Marlene, que tinha a vantagem do contencioso com Emilinha - e da Radiolândia 36 vezes até 1960" (2006, p.9). 
Nacional e que despreza “o 'bolero' cantado por Ângela Maria”, considerando-o um caso típico de "cultura 'inautêntica', de importação, mesmo se produzida no Brasil” (Fabris, 1994, p.172). No entanto, não há como subestimar o olhar que Espírito dirige a Ângela Maria caso se queira compreender a esperança do sambista de morro e, por conseguinte, os conflitos que se instalam entre o seu ponto de vista, o do diretor Nelson Pereira dos Santos e o de Moacyr. ${ }^{11}$

Ora, desde pelo menos Constantin Stanislavski, sabemos que qualquer intérprete toma de si os afetos “análogos aos que o papel requer": os afetos da própria ou do próprio intérprete são recolhidos e expressados a partir de um processo que implica "compreender um papel, simpatizar com a pessoa retratada e pôr-se no lugar dela" (Stanislavski, 2006, p.216; grifo do autor). Esse processo se vincula diretamente à valorização estética de Ângela Maria. Ela era vista "como um exemplo real de artista vinda do povo" pois, antes de se tornar cantora profissional, havia trabalhado "em uma fábrica de lâmpadas" e fora "operária em uma indústria de tecidos" (Silva, 2013, p.174). Além disso, uma anedota bastante divulgada conta que Ângela ganhara do presidente Getúlio Vargas o apelido de Sapoti, pela voz doce e pela cor da sua pele (Sovik, 2006, p.10). Na avaliação de Liv Sovik, a cantora "e sua música existiam no limiar entre ser negro, ou 'sapoti', e a suspensão dessa identidade - algo como Blackout, outro cantor da época, cujo nome indica simultaneamente negritude e a ausência de cor" (2006, p.11). Todos esses traços são interessantes e auxiliam no entendimento da relação entre Espírito e a cantora. No entanto, na perspectiva crítica que adoto, mais do que pesquisar a biografia e a imagem de Ângela Maria, importa investigar a alma de "Fechou o paletó", a qual a cantora deve compreender para pôr-se no lugar dela.

\section{Os sentidos de "Fechou o paletó"}

Formulemos, assim, a pergunta: qual é a alma desse samba? "Fechou o paletó" é composto por Espírito da Luz Soares a partir de uma experiência complexa; e terrível, ainda que os traços melodramáticos do filme acabem por atenuar o mal-estar. ${ }^{12}$ A primeira camada desta experiência, conforme analisou Mariarosaria Fabris (1994, p.181), diz respeito aos fatos mais diretamente implicados no processo de composição: o samba possibilita a Espírito "reelaborar a perda do filho" Norival e, ao cantá-lo como um "típico malandro", tomar "consciência da própria marginalização". Todavia, para melhor esclarecer esse ponto e seguir adiante na análise, será necessário resumir brevemente a narrativa.

Espírito ficara viúvo quando Norival nasceu, e o filho cresceu no patronato. Com 15 anos, é apanhado pelo pai quando tenta assaltar seu Figueiredo, patrão

11 Para o estudo dos pontos de vista da narrativa de Rio, Zona Norte, baseio-me em Ismail Xavier (1997), Carolinne Mendes da Silva (2013) e Grazieli Chirossi Batista (2017). Para a discussão da relação entre o ponto de vista do diretor Nelson Pereira dos Santos e o do personagem Moacyr, consultar Mariarosaria Fabris (1994, p.162-163; 196-197) e Luis Felipe Kojima Hirano (2014, p. 248-249).

12 Sobre a estrutura do filme à luz do melodrama, consultar Carolinne Mendes da Silva (2013, p.49-55). 
cordial13 de Espírito. O sambista discute com Adelaide, com quem está recémcasado. Ela não quer que Norival more com eles. A bem da verdade, Adelaide é uma mulher com senso prático: empregada em casa de família, com um filho de colo para criar, ela estava cansada de esperar que o companheiro ganhasse dinheiro ou ficasse famoso. Norival sai do barraco de alvenaria. Espírito procura-o, vai ao barraco de pau a pique onde estão os amigos que com ele haviam fugido do patronato. E acaba entregando ofilho: os amigos imaginavam que Norival vacilara, que ficara com o dinheiro do assalto, mas ele o devolvera a seu Figueiredo.

Na discussão que tem com Adelaide, Espírito grita: "Eu sou um compositor. Posso muito bem te sustentar com as minhas músicas e te fazer feliz, se você quiser". Então, vai à Rádio Nacional (esta será a segunda vez que o vemos lá), onde é passado para trás pelo comprositor Maurício Silva, que lhe faz escrever uma declaração, "Não tenho nada a ver com o samba 'Mexi com ela", em troca de algum dinheiro; adiante retomarei o ponto. ${ }^{14}$ Quando retorna ao morro, o sambista percebe que Adelaide o abandonara. Os amigos de Norival o assaltam. $O$ filho, que estava no barraco em frente, sai em defesa do pai e é assassinado. $O$ jornal transforma a morte em notícia sensacionalista. Na mercearia de seu Figueiredo, Maurício mal dá os pêsames: está ali para dizer que Espírito precisa assinar um documento formal na gravadora. O sambista fica alheio, está escrevendo. Maurício tenta ler, e Espírito empurra-o com força: diz que o samba é seu e que será gravado por Ângela Maria (Santos, 1957).

Penso que agora se pode avaliar melhor a primeira camada de sentido. "Fechou o paletó" reelabora a dor e a culpa do assassinato de Norival. Ao mesmo tempo, os versos de Espírito, quando transformam o filho em mais um malandro pobre que morre de forma violenta, cantam a própria situação do sambista expropriado, colocado à margem do mercado de canções. Mas a essa camada, que é espessa, se junta uma segunda: o samba é também uma resposta a Adelaide, cujo senso prático não suportou a espera indefinida por projeção social ou segurança financeira.

A análise, contudo, ainda não está completa. Vejamos a terceira camada de sentido. Mariarosaria Fabris (1994, p.161-162) chamou atenção para quatro sambas cantados no terreiro, logo no início do flashback, que fazem "uma espécie de resumo da trajetória sentimental de Espírito”, antecipando a sua relação com Adelaide e também o acidente no trem: "Mexi com ela", "Dama de ouro", "Mágoa de sambista" e "Grito de uma raça”. ${ }^{15}$ E Fabris (1994, p.167) ainda apontou dois prenúncios da morte de Espírito a que assistimos nos momentos iniciais do filme: a conversa entre Espírito e sua afilhada Gracinda, "quando ela diz que o samba 'Não

13 A expressão é tomada de empréstimo à peça teatral $O$ patrão cordial, dramaturgia e direção de Sérgio de Carvalho, encenada pela Companhia do Latão em 2013. O espetáculo foi inspirado em Raízes do Brasil, de Sérgio Buarque de Holanda, e em O Sr. Puntila e seu criado Matti, de Bertolt Brecht. Uma análise comparativa, todavia, encontraria mais diferenças que semelhanças entre seu Figueiredo e o personagem Cornélio, d' O patrão cordial, o que sugere a variedade das relações de mando pautadas pelos afetos positivos ou negativos.

14 Segundo João Antônio, na década de 1980 ainda havia evidências de que se compravam canções: "Os compradores são chamados, no Rio [de Janeiro], de comprositores" (Rosa, 1982, p.93).

15 Segundo a ficha técnica, "Mexi com ela", "Dama de ouro" e "Mágoa de sambista" são de autoria de Zé Kéti; "Grito de uma raça", de Vargas Júnior (Santos, 1957). 
quero morrer agora' dava direitinho para a voz de Ângela Maria”; e a cena em que Espírito, caído nos trilhos, desperta após uma mulher se aproximar segurando uma vela. Levando adiante essas observações, espero não extrapolar afirmando que "Fechou o paletó", além de recriar o assassinato de Norival, funciona como mais um agouro da morte de Espírito da Luz Soares. Isso ocorre porque o samba também pode ser escutado como a condensação dos últimos acontecimentos na vida do sambista, incluindo até mesmo o relato da sua morte. Uma vez mais, será preciso sumariar a narrativa.

Para atender à solicitação de Ângela Maria e ver o seu samba valorizado no mercado hegemônico ("Você traga a parte de piano, que eu vou mandar fazer um bonito arranjo e vou gravar"), Espírito procura Moacyr, artista e intelectual de classe média. Já assinalei que ele trabalhava como violinista em uma das orquestras da Rádio Nacional - e, enquanto acompanhava Ângela em "Pretexto", exibia a caricatura de imenso tédio. Subindo o morro e assistindo ao ensaio da Escola de Samba Unidos da Laguna, Moacyr se interessara pela produção de Espírito. Chegara a pedir para o compositor cantar só a melodia, sem a letra, o que revela a distância entre o seu interesse e a forma cancional do samba de terreiro. De sua parte, Espírito sempre se comportou como se a amizade com Moacyr fosse um meio para alcançar o encontro que de fato lhe importava, com Ângela Maria. Ocorre que o bordão de Moacyr era "Precisamos conversar", e conversar com ele nunca era fácil, como reclamou Espírito a certa altura. Na verdade, a execução do projeto estético de Moacyr, assim como o oferecimento de qualquer ajuda a Espírito eram postergados continuamente, e o sentimento que parecia dominá-lo era "o da preguiça diante do mundo" (Melo, [s.d.], [s.p.]). Mais do que uma característica do personagem, a preguiça sintetizava a relação dos "intelectuais de esquerda" com a cultural popular, como Nelson Pereira dos Santos afirmou em entrevista a Mariarosaria Fabris (1994, p.196-197).

Assim que é recebido no apartamento de Moacyr, Espírito diz: "Eu vim trazer um samba pro senhor, porque eu preciso da música escrita”. O músico erudito responde: "Ah, então vamos fazer isto já. [E para os amigos que estão na sua sala] Este é o maior sambista vivo". Elogios também são ditos por Helena - "uma mulher de classe, [que] parece presidir a vida" do marido (Fabris, 1994, p.180) -, interessada que está em exibir-se demarcando a sua superioridade: "Ele tem cada samba fabuloso. Vocês precisam ouvir. Canta um pouquinho, canta" (grifo meu). Espírito tira do bolso um papel com a letra de "Fechou o paletó". Vai entregá-lo ao violinista, mas Helena puxa a folha.

Espírito batuca na caixa de fósforo e apenas entoa um trecho de "Fechou o paletó". Escuta alguns comentários pernósticos daqueles amigos de Moacyr e Helena, o violinista alardeia que tem "vontade de fazer um balé com as músicas dele", Espírito silencia, apanha a sua letra largada sobre a mesinha de centro e vai se retirando. Moacyr caminha até ele, mas acaba dizendo para Espírito voltar no dia seguinte, a fim de que a música seja escrita na partitura. Espírito vai embora, pega o trem para voltar ao morro. Desiludido, parece que vai jogar pela janela os papéis com as suas composições. Mas escuta dois jovens conversando sobre 
o samba àquela noite e sobre o próximo carnaval. Guarda os papéis no bolso. Sente-se inspirado. Compõe um novo samba, pendurado na porta aberta do trem superlotado. Anônimo, ignorado pelas pessoas à sua volta, Espírito da Luz Soares batuca, canta, gargalha. E cai nos trilhos, simbolizando a "agonia e [o] êxtase do gênio da nação-povo" (Napolitano, 2014, p.82). É levado ao hospital, passa por cirurgia, mas não resiste.

O que resta da sua obra? Honório, compadre de Espírito, diz a Moacyr que muita gente no morro conhece "três ou quatro sambas", "os melhores" (Santos, 1957). Novamente estão presentes elementos comuns na prática da música de tradição oral: o processo de transmissão e o de permanência garantidos pela comunidade, a qual prescinde da escrita ou do fonograma. Mas o melhor samba é "Fechou o paletó", e não houve tempo para ninguém aprendê-lo. Sabemos que está perdido, seria muito otimismo confiar na memória musical de Ângela Maria, que ficou com a letra, ou na daquele violonista. Afirmo que é o melhor samba porque - espero que o resumo da narrativa tenha indicado - "Fechou o paletó", em sua terceira camada de sentido, reelabora o assassinato de Norival desde os primeiros versos, "Mais um malandro fechou o paletó/ Eu tive dó, eu tive dó..., até o primeiro refrão; a seguir, nos versos cantados por Ângela Maria, passa a narrar a morte de Espírito, "Céu estrelado, lua prateada/ Muitos sambas, grande batucada/ O morro estava em festa quando alguém caiu/ Com a mão no coração, sorriu...."

Nessa chave interpretativa, que se inspira no trabalho de crítica de José Antonio Pasta Jr., a estrutura do samba é entendida "a partir da decomposição da própria consciência”, encapsulando o desenvolvimento parcial do filme em flashback: sem deixar de conter os sentidos anteriormente apontados, "Fechou o paletó" se constitui no "limite entre a vida e a morte" do sujeito que canta, no paradoxo do seu "instante mortal” (Pasta Jr., 2012, p.6 e 9; grifo do autor). Resta examinar, de modo mais preciso, os vínculos entre Espírito e a malandragem; e indagar, nesse quadro, quem seria, afinal, "o criminoso [que] ninguém viu”.

Se "Fechou o paletó" era a própria alma do seu autor, o "Espírito da Escola de Samba", então ela se oferecia por inteiro, doce e atravessada de sofrimentos, a uma das Rainhas do Rádio - aquela que seria capaz de compreendê-la. Caso essa alma fosse gravada por Ângela Maria, iria adquirir a visibilidade que lhe faltava. Ocorre que o mercado de canções e o morro eram dois mundos diversos, e Espírito não ocupava um lugar definido em nenhum deles. Desse ângulo, o nome Espírito da Luz Soares, além de cifrar "Espírito de Luz [que] é um espírito superior, mais puro, que comanda os espíritos sem luz" na Umbanda (Fabris, 1994, p.197), sinaliza uma matéria que, "só ares", carecia de um corpo sólido.

No morro, Espírito era um malandro, um otário e também, com perdão pelo termo, um vagabundo. Procurarei detalhar essa construção complexa. Em relação à malandragem, não há dúvida de que várias cenas de Rio, Zona Norte, "no espaço alternativo da favela", retratam a "persistência de formas populares tradicionais de solidariedade e assistência recíproca que contrastam com as relações capitalistas de trabalho, em que a competição é o elemento fundamental" (Fabris, 1994, 
p.169-170). Espírito morava de favor em barraco de alvenaria do seu compadre Honório, o que exemplifica a solidariedade e a assistência entre amigos. ${ }^{16}$ Mas essa forma de sociabilidade se esgarçava quando Honório, empregado formalmente, ainda arranjava material para o que seria a "tendinha do Espírito" e era o único a trabalhar na construção, até mesmo durante a noite. 0 sambista também agia com certa dose de malandragem quando sobrevivia de pequenas tarefas que eram adiadas conforme a própria conveniência e cobradas com simpatia, por antecipação, do patrão cordial, seu Figueiredo: "O trabalho fica pra amanhã, mas o dinheiro, eu precisava dele hoje mesmo”. Nesses dois casos, não é difícil perceber que, embora não se comportasse com ostensiva violência, Espírito tirava vantagem de situações informais pautadas por relações de afeto, de forma hábil.

Por outro lado, o sambista era um otário no morro, no sentido de ingênuo, frente à delinquência, dinâmica na qual seu filho e os amigos do patronato sobreviviam. E que não devia ser desconhecida de Espírito: "Mais um malandro fechou o paletó" - não era o primeiro, não haveria de ser o último. Finalmente, "Diferença de malandro", samba da década de 1930 composto por José Gonçalves e Artur Costa, já dizia que "o malandro vive na cidade/ Gozando as delícias que tem neste mundo/E o vagabundo fica lá no morro/ Cantando samba pra beber cachaça/ De boca aberta, bancando o palhaço/ E o malandro para isso não se passa/ (...) Mas o malandro vai pro microfone" (Tinhorão, 1981, p.129). ${ }^{17}$ Assim, do ponto de vista do comprositor Maurício Silva - que, ao se apropriar do samba "Mexi com ela", atuara em conluio com o cantor em ascensão Alaor da Costa e com o discotecário Waldemar -, Espírito era um vagabundo. ${ }^{18}$

Esse último ponto nos leva ao mercado de canções. Nele o sonho de Espírito era o de ser otário, só que no sentido de ser um trabalhador, o que ele não conseguia ou por estar enredado na trama da malandragem ou por encontrar pessoas bem-intencionadas, como Moacyr e Ângela Maria, incapazes de "despojar-se da própria posição de classe e ver as reais condições do compositor" - o violinista, por razões que já foram expostas; a cantora, por haver se mostrado "incapaz de perceber que Espírito não [tinha] meios para transpor sua música para a partitura" (Hirano, 2014, p.247). Curioso processo. Nesse mercado, o Espírito da Escola de Samba desejava assinar contrato. Desejava poder cantar decentemente

16 Fugiria aos propósitos deste ensaio levar adiante a reflexão sobre a solidariedade e a assistência entre Espírito e Honório. De todo modo, registre-se que o sambista não se enquadra propriamente na categoria de agregado. Na prática, os laços entre os dois amigos são os de parentesco, já que Espírito é o padrinho da filha de Honório, Gracinda. Note-se que batizar uma criança, por si só, não define esses laços: para não fugir à narrativa do filme, basta lembrar que seu Figueiredo batizou Cláudio, filho de Adelaide, e nem por isso o parentesco se firmou. Ou seja, o que vemos em Rio, Zona Norte, em última análise, é que a esfera econômica, atravessada pelas questões de raça e de gênero, é a instância decisiva: uma coisa é a relação entre duas pessoas pobres como o negro Espírito e o branco Honório; outra coisa, bem diferente, é a relação entre o dono branco da mercearia do morro e uma mulher negra que trabalha em casa de família. Para ampliar a discussão, seria interessante comparar esse quadro com o das relações entre a família de Bentinho e o agregado José Dias, personagens do romance Dom Casmurro, de Machado de Assis (1971), a partir da crítica de Roberto Schwarz (1997).

17 Tinhorão (1981, p.129) transcreve a letra de "Diferença do malandro" do "jornal de modinhas A Voz do Mundo, de agosto de 1936, p. 2". Parte do samba foi cantado, com letra ligeiramente diferente, pela Velha Guarda da Mangueira no programa televisivo Tudo é Música, apresentado por Tinhorão e produzido pela TVE do Rio de Janeiro em 1981 (VV.AA., 1981); devo a indicação desse vídeo a Rachel Sciré. 
O Espírito da Escola de Samba nos...

a malandragem, conquistar uma identidade e, com sorte, "contornar parte de suas dificuldades materiais" como fizeram alguns sambistas desde a década de 1930 (Sandroni, 2012, p. 180). 0 artista negro, morador do morro, desejava, em suma, viver dentro da ordem - algo que se mostrou impossível para esse personagem típico sem lugar definido na sociedade e sempre em condições precárias de sobrevivência. 


\section{Bibliografia}

" Aguiar, J. A. (2002). Elis Regina: cantora do Brasil. In: Vidal, A. J. y Aguiar, J. A. Leniza \& Elis. São Paulo: Ateliê Editorial.

" Azevedo, F. (s.d.). Método de violão [25a ed.]. Rio de Janeiro: Edição do Autor.

"Batista, G. Ch. (2017). A irmandade fraturada: a relação entre os intelectuais de esquerda e as camadas populares no filme Quase dois irmãos (Lúcia Murat, 2005). (Dissertação). Universidade de São Paulo.

" Chediak, A. (1984). Dicionário de acordes cifrados: harmonia aplicada à música popular [ $4^{a}$ ed.]. Rio de Janeiro: Irmãos Vitale.

" Fabris, M. (1994). Nelson Pereira dos Santos: um olhar neo-realista? São Paulo: Edusp/ Fapesp.

"Hirano, L. F. K. (2014). O gestus social em Rio Zona Norte: notas para um diálogo entre ator e diretor na análise cinematográfica. In Tomo, № 25. p. 248-249.

" Leão, N. "Malvadeza Durão". Autor: Zé Kéti. In: Leão, N. O canto livre de Nara. Universal Music, 73145463372/ SET 73145863262, 2002 [p1965]. 1 CD.

" Kéti, Z. "Malvadeza Durão". Autor: Zé Kéti. In: LEÃO, Nara; KÉTI, Zé; Vale, João do. Show Opinião. Universal Music, 73145224002/ SET 73145863262, 2002 [p1965]. 1 CD.

" Machado de Assis, J. M. (1971). Dom Casmurro. In Machado de Assis, J. M. Obra completa, volume 1, org. Afrânio Coutinho [3를. ed.]. Rio de Janeiro: José Aguilar.

"Marçal, J. (2012). "Malvadeza Durão". Autor: Zé Kéti. VÁRIOS. Cancioneiro de Boal. São Paulo. Arquivo em mp3, registro de ensaio.

"Melo, L. A. R. (s.d.). Rio Zona Norte. In Contracampo: Revista de cinema, no 80, [s.p.]. Disponível em: http://www.contracampo.com.br/8o/riozonanorte.htm. Acesso em: 9 abr. 2021.

"Napolitano, M. (2014). Rio, Zona Norte (1957) de Nelson Pereira dos Santos: a música popular como representação de um impasse cultural. In Per Musi, no29, p.75-85. Disponível em: http://www.scielo.br/pdf/pm/n29/n29a09.pdf. Acesso em: 9 abr. 2021.

"Pasta Jr., J. A. (2012). O ponto de vista da morte: uma estrutura recorrente da cultura brasileira. In Revista da Cinemateca Brasileira, № 1, p.6-15.

" RACIONAIS MC'S. (1997). "Tô ouvindo alguém me chamar". Autor: Mano Brown. In: RACIONAIS MC'S. Sobrevivendo no inferno. Cosa Nostra/ Zambia, ZA o01. 1 CD.

" Rezende, G. S. S. L. (2021). A história (des)contínua: Jacob do Bandolim e a tradição do choro. São Paulo: Alameda.

" Rosa, N. (1982). Literatura comentada - Noel Rosa; seleção de textos, notas, estudo biográfico, histórico e crítico e exercícios por João Antônio Ferreira Filho. São Paulo: Abril Educação.

"Sandroni, C. (2012). Feitiço decente: transformações do samba no Rio de Janeiro (1917-1933) [2르 ed., ampliada]. Rio de Janeiro: Zahar.

"Santos, Nelson Pereira dos. (1957). Rio, Zona Norte. Rio de Janeiro.

"Saroldi, L. C. y Moreira, S. V. (1988). Rádio Nacional: o Brasil em sintonia [2ª ed.]. Rio 
O Espírito da Escola de Samba nos...

de Janeiro: Martins Fontes/ Funarte.

"Schwarz, R. (1997). A poesia envenenada de Dom Casmurro. In Schwarz, R. Duas meninas. São Paulo: Companhia das Letras.

"Silva, C. M. (2013). O negro no cinema brasileiro: uma análise fílmica de Rio, Zona Norte (Nelson Pereira dos Santos, 1957) e A Grande Cidade (Carlos Diegues, 1966). Dissertação. Universidade de São Paulo.

"Sodré, M. (1998). Samba, o dono do corpo [2ª ed.]. Rio de Janeiro: Mauad.

"Sovik, L. (2006). Um lírio em lamaçal: a identidade cultural brasileira na música dos anos 50. In 15 Encontro Anual da COMPÓS, p.1-23. Disponível em: http://www. compos.org.br/data/biblioteca_457.pdf. Acesso em: 9 abr. 2021.

"Stanislavski, C. (2006). A preparação do ator; trad. Pontes de Paula Lima [23a ed.]. Rio de Janeiro: Civilização Brasileira.

" Tinhorão, J. R. (1981). Música popular: do gramofone ao rádio e TV. São Paulo: Ática.

" Tinhorão, J. R. (1991). Pequena história da música popular: da modinha à lambada [6ạ ed. revista e aumentada]. São Paulo: Art Editora.

" Tinhorão, J. R.. (1997). Música popular: um tema em debate [3 $3^{\underline{a}}$ ed. revista e ampliada]. São Paulo: Editora 34.

" VV.AA. Programa Tudo é Música - Resgate TVE. Rio de Janeiro, 1981.

"Xavier, I. (1997). O olhar e a voz. A narração multifocal do cinema e a cifra da História em São Bernardo. In Literatura e Sociedade, v.2, no 2, p.126-138. 